Article

\title{
Qualification of brazing procedure for furnace brazing of austenitic steel according to requirements of the ASME BPVC, section IX
}

\author{
Grzegorz Rogalski ${ }^{1}{ }^{*}$, Michał Landowski ${ }^{1}$, Aleksandra Świerczyńska ${ }^{1}$, Jerzy Łabanowski ${ }^{1}$, Jacek Tomków ${ }^{1}$ \\ ${ }^{1}$ Gdańsk University of Technology, Poland \\ Michał Landowski, Ph.D.; miclando@pg.edu.pl; \\ Aleksandra Świerczyńska, Ph.D.; aleswier@pg.edu.pl; \\ Prof. Jerzy Łabanowski; jerzy.labanowski@pg.edu.pl; \\ Jacek Tomków, Ph.D.; jacek.tomkow@pg.edu.pl; \\ *Correspondence: Grzegorz Rogalski, Ph.D., D.Sc.; grzegorz.rogalski@pg.edu.pl
}

Received: 30.04.2019; Accepted: 29.07.2019

\begin{abstract}
The article presents the procedure for qualifying brazing technology in a vacuum furnace on the example of stainless steel elements joined with copper filler material from the F-No group. 105, in accordance with the ASME Sec. IX, part QB (ASME Boiler and Pressure Vessel Code. Qualification Standard for Welding, Brazing and Fusing; Procedures; Welders; Brazers; and Welding, Brazing and Fusing Operators). The essential variables of the furnace brazing process are discussed in relation to the requirements of the protocol of qualified PQR (Procedure Qualification Record) and BPS (Brazing Procedure Specification) in accordance with the ASME Sec. IX. The requirements for joints by the calculation code ASME Sec. VIII div.1 (Rules of Construction of Pressure Vessels), related to the working temperature of the designed device have also been taken into account. The paper presents examples of brazed joints made and their properties (strength, fill level of the clearance) obtained on the basis of the carried out tests. Attention was paid to the technological aspects during the performance of brazed joints using vacuum furnaces.
\end{abstract}

Keywords: brazing; furnace brazing; austenitic stainless steel

\section{Introduction}

One of the welding processes that is widely used in many sectors and industrial branches is brazing, which is a process that allows joining metals using various types of heat source and brazing filler metal,

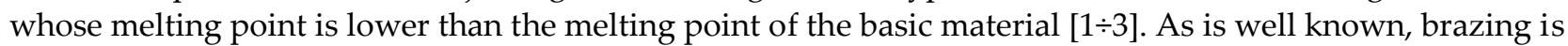
one of the oldest methods of welding apart from mechanical joining. Initially, it was used to combine materials based on silver and gold, and then with the development of metallurgy to produce other construction materials, e.g. unalloyed and alloy steels, stainless steels, nickel and its alloys, titanium and its alloys, and even aluminium. In the initial stage, brazing filler metal were used, which were characterized by a low melting point. They were lead, tin, gold-copper and silver-copper alloys. Subsequently, filler metal was modified by adding copper hydrates and organic resins that reduce. This allowed minimizing oxidation and improving the appearance of the connection. Along with the development of brazing technology and construction materials, brazing filler metal in terms of chemical composition and form (rods, foils, pastes, powders) also underwent dynamic development. This made it possible to obtain brazed joints with high strength parameters and operational properties (e.g. corrosion resistance). In addition to the properties of the materials to be joined and brazing filler metal, physicochemical phenomena and the associated mechanisms of joint formation play an important role. The following physicochemical factors affecting the formation of brazed joints can be distinguished: wettability, flowability, fluidity, diffusion and mutual solubility of filler components and base material, filler metal crystallization [4,5]. All these elements have a significant impact on the mechanisms of creating brazed joints with the required properties. This confirms the complexity of the brazing process and ranks it in a group of special processes. For this reason, it is described by many basic variables that must be included at the stage of brazing technology qualification and are presented in relevant regulations and subject standards [6,7]. 
Among many brazing variations (brazing temperature $\mathrm{T}>450{ }^{\circ} \mathrm{C}$ ), brazing in vacuum furnaces can be

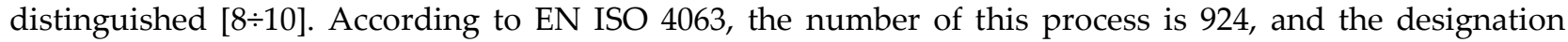
according to ASME Sex. IX is FB (Furnace Brazing). The beginnings of the use of vacuum brazing are associated with the aviation industry, where turbine engine components were combined. This allowed to obtain joints of very good quality and high strength due to the use of high vacuum. This is due to the lack of oxide inclusions and gas bubbles. The reduction of gas bubbles is due to the minimum amount of gas present in the brazing atmosphere. The value of vacuum is one of the important factors of this type of process due to the occurring reactions of oxide dissociation and desorption of gaseous components from the surface of the materials to be joined. An inadequate vacuum value may lead to the appearance of oxide deposits on the joined surfaces and other incompatibilities or defects in the joints. For selected construction materials, it can have the following ranges of values [11]:

1. Carbon, mild and tool steels: $\min .1 \mathrm{~Pa}\left(10^{-2} \mathrm{mbar}\right)$.

2. Stainless steels: min. $10^{-1} \mathrm{~Pa}\left(10^{-3} \mathrm{mbar}\right)$.

3. Nickel alloys (heat-resistant): $10^{-2} \div 10^{-3} \mathrm{~Pa}\left(10^{-4} \div 10^{-5} \mathrm{mbar}\right)$.

Another important phenomenon that can occur during the brazing process is the sublimation of alloying components of the combined materials. To reduce them, the inert gas is introduced into the furnace working chamber. The amount of gas must be sufficient to ensure that the chamber pressure is maintained at $50 \mathrm{~Pa}(0.5 \mathrm{mbar})$ [11]. The basic parameters of vacuum brazing include: heating speed $\left({ }^{\circ} \mathrm{C} / \mathrm{min}\right)$, brazing temperature and brazing time $\left({ }^{\circ} \mathrm{C}, \mathrm{min}\right)$, temperature and time of temperature stops if used $\left({ }^{\circ} \mathrm{C}\right.$, min), vacuum pressure (mbar), cooling speed $\left({ }^{\circ} \mathrm{C} / \mathrm{min}\right)$, partial pressure of inert gas introduced into the working chamber (bar) and filling time (min). Vacuum brazing is usually associated with high temperatures, usually from $927^{\circ} \mathrm{C}$ to $1232^{\circ} \mathrm{C}$ and no need to use flux in the process [12]. An example of the process of vacuum brazing is shown in figure 1 . Stage 1 - allows solvents or water in a paste or binder to degass from filler braze metal, restores the quality of the atmosphere, which can deteriorate from the resulting gases, Stage 2 - in this stage organic substances (not liquids) in the filler metal have enough time to go into the gas phase and be removed by the furnace pumping system, Stage 3 - temperature stabilization below the temperature of the brazed material, Stage 4 - holding time at the set temperature, allows the filler braze metal to melt and fill the joint clearance. Cooling below the solidus temperature of the brazing filler metal, Stage 5 - additional cycle with holding at a temperature lower than in stage 4, cooling speed suitable for reducing deformation.

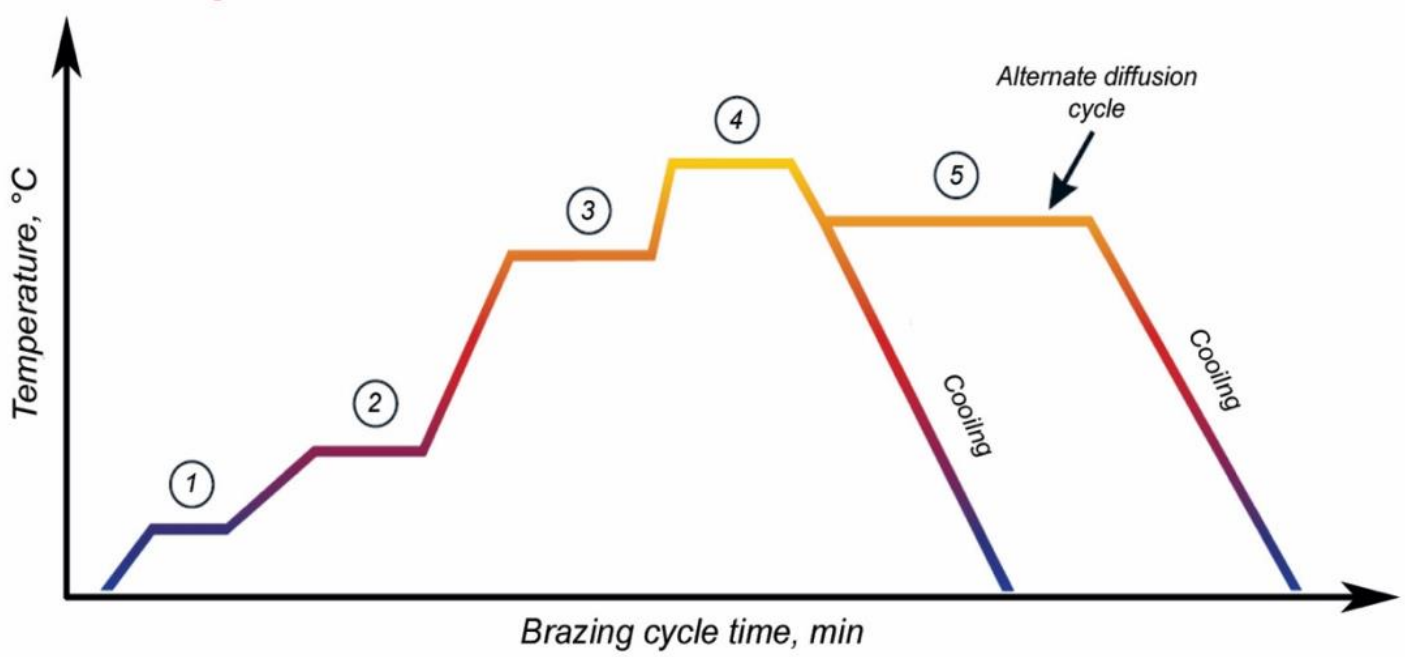

Fig. 1. Exemplary heating and cooling cycle for furnace brazing [13]

In addition to the main parameters of brazing in the technological cycle, it is necessary to take into account additional processes, which also play an important role. They are related to the geometry of the elements to be joined (type of brazed joint), preparation of elements for brazing (surface cleaning, machining), assembly of elements (preservation of the brazing gap of the appropriate value), application of additional coatings (e.g. increasing wettability), method of brazing in depending on the type of production and its form (paste, tape, rod insert, etc.). All of these factors must be properly correlated with brazing parameters. This allows connections to be made that have the required quality in terms of strength and performance [14]. In addition, it should be noted that due to the even and controlled heating and cooling of the joined elements, deformations occurring during the brazing process are minimized, which is an 
undoubted advantage in relation to other welding processes. At the same time, the repeatability of the process is at a very high level, which also affects the quality of the products obtained.

The mentioned advantages of the vacuum brazing process were quickly noticed by specialists in welding engineering and companies from sectors related to broadly understood energy. One of the commonly used devices in the area of heat distribution management are various types of heat exchangers. The most common heat exchangers in the industry include non-contact heat exchangers from the group of simple recuperators (fluids are separated by a wall across which heat exchange occurs). These include shell and tube heat exchangers and plate heat exchangers. The latter achieve twice higher heat transfer coefficients than shell and tube heat exchangers. For this reason, they are characterized by high efficiency at compact sizes, which allowed their wide application. Typical applications are heating, cooling, swimming pool installations, central heating installations and in waste heat systems. They can be used in installations powered from heating networks, as well as in those using renewable energy sources such as solar collectors and heat pumps. Exchangers of this type are very often made as brazed. Examples of brazed heat exchangers from SECESPOL Sp. $z$ o.o. is shown in figure 2.

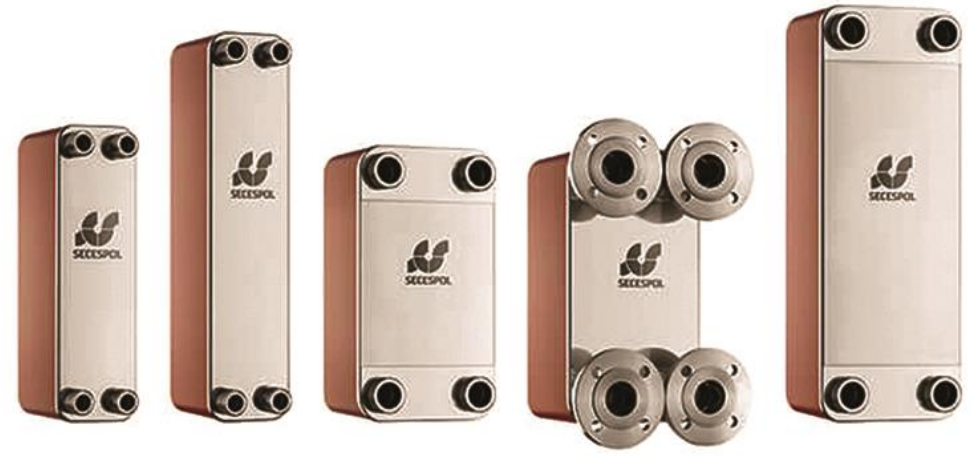

Fig. 2. Examples of brazed plate heat exchangers from SECESPOL Sp. z o.o. [15]

Brazed heat exchangers are made of various construction materials, including nickel and its alloys. However, the most common material group is high-alloy stainless austenitic steels. The amount of literature on welding steel from this material group is very large. Research is conducted focused on various aspects, including: the effect of supersaturation temperature on the properties of welded joints [16,17], surfacing technology [18], tests related to determining the corrosion resistance of welded joints [19] and others. In the case of vacuum brazing, reports are less numerous, which results from the high degree of complexity of this process and the know-how of the companies that use this process.

Brazing, like welding and gluing, is included in the group of special processes. In accordance with applicable standards (e.g. ISO 9001, EN ISO 3834, EN 1090 and others), these processes must be constantly monitored and supervised at every stage of application. One of the many ways that allows these requirements to be met is the testing of the welding technology (the so-called qualification) to be used and the certification of the personnel using the joining process. For this reason, many subject standards and international and national regulations have been created that regulate these issues. This approach and behavior allows us to prove that the welding technology used, taking into account the so-called principal variables, guarantees the achievement of welded or brazed joints that meet specific or assumed acceptance criteria. These criteria are given in standards, regulations and technical specifications and relate, among others, to strength properties, metallographic structures, corrosion resistance and others. This allows for the unification of requirements in the area of applied processes and clearly defines the criteria that must be met. This, in turn, gives the opportunity to use such technology developed for the production of equipment sold to various markets in which these requirements apply. European and international standards regarding the qualification of brazing technology and examination of brazers for this process are as follows: PN-EN 13134: 2004 - Brazing. Procedure approval; PN-EN ISO 13585:2012 - Brazing. Qualification test of brazers and brazing operators. At the same time, other standards are associated with these standards, among others, regarding additional materials for brazing according to PN-EN ISO 17672:2010 (Brazing. Filler Metals) and performing destructive tests according to PN-EN 12797:2002/A1:2005 (Brazing. Destructive testing of brazed joints) and non-destructive joints according to PN-EN 12799:2003/A1:2005 (Brazing. Nondestructive examination of brazed joints). These standards apply to various products including pressure equipment manufactured for the European and international market. Recognition of brazing technology and certification of personnel performing this type of joints according to the cited standards have been widely described in the available literature [6,7]. 
At present, many companies manufacture their products for markets other than European, e.g. to the USA, Canada, Mexico and others. In these countries, European and very often international standards do not apply due to the existence of other own local regulations. This is the case when we manufacture pressure equipment for the US, Canadian, Mexican and other South American, Asian and African markets. In this case, the regulations created by the American Society of Mechanical Engineers (ASME) are used. They play a similar role as the requirements of the pressure directive PED 2014/68/WE. Meeting these requirements makes it possible for the manufactured devices to flow freely in the area in which they apply. Manufacturers outside the US and Canada can apply for ASME accreditation since the 1970s. Interestingly, the number of manufacturers from countries other than the USA and Canada, accredited by ASME and possessing the socalled stamp holders in 2010 exceeded the number of US companies accredited in accordance with ASME regulations. This demonstrates the very large potential in this area of activity. ASME has been officially active since 1880 (Henry R. Worthington, Alexander Lyman Holley and John Edson Sweet, together with other industrialists and technical innovators gathered in New York for the first time), and the regulations published since 1914 are constantly developed and updated as their subsequent editions (last edition in 2019). They are created on a voluntary basis by a group of experts and engineers who represent users, inspection units and producers grouped in different committees. It should be noted that American manufacturers also ship their products to the European market. This led to the introduction of changes that harmonize the regulations of ASME Code with the requirements of European standards. An example of this type of proceedings may be ASME Code, Sec. VIII, Div.2 (regulations for vessels), which in its structure became similar to the standard EN 13445 (Unfired pressure vessels). The ASME BPVC (Boiler and Pressure Vessel Code) regulations consist of 12 sections covering various areas of engineering in the broad sense. Half of them are design requirements that relate to the certification of devices, three are related to design regulations, and the next three are operational regulations (applicable after installing the devices). The listed sections are as follows [20]:

1. Construction rules

a) Section I - Power Boilers;

b) Section III - Div.1, Div.2, Div.3 - Nuclear Facility Components;

c) Section IV - Heating Boilers;

d) Section VIII - Div.1, Div.2, Div.3 - Pressure Vessels;

e) Section X - Fiber-Reinforced Plastic Vessels;

f) Section XII - Transport Tanks;

g) Regulations B 31.1 - Power Piping.

2. Other regulations related to construction regulations

a) Section II - Materials: Part A - Ferrous Material Specifications; Part B - Nonferrous Material Specifications, Part C - Specification for Welding Rods, Electrodes and Filler Metals, Part D Properties,

b) Section V - Nondestructive Examination;

c) Section IX - Welding and Brazing Qualification.

As in European and international regulations, all ASME Code regulations contain references to other standards issued by industry organizations, e.g. AWS, ASTM, ANSI, API, ISO. Importantly, they also provide the dates of editing selected norms acceptable by ASME. This is of great importance, among others, in the selection of basic materials that must meet strict criteria, e.g. other requirements for samples determining the value of elongation. ASME offers a constantly changing portfolio of standards in a wide range, including for pressure equipment, power plants, elevators, construction equipment, pipelines, nuclear components and others.

\section{Own research}

The purpose of the work is to present guidelines related to the qualification process of vacuum brazing technology in accordance with the requirements of ASME BPVC, Sec. IX on the example of highalloy austenitic stainless steel vacuum brazed joints.

\section{Qualification of vacuum brazing technology for plate heat exchanger components}

The subject of the analysis of requirements of the regulations of ASME Sec. IX and ASME Sec. IX div. 1 is a plate heat exchanger, whose constructions are shown in figure 3.

The heat exchanger is a flow and countercurrent device. The heat exchange surface is formed by corrugated heating plates (Fig. 3) (different geometries) connected in a package by brazing. Appropriate 
shape of the internal space of the exchanger directs the flow of heat exchange fluids into the channels created by every second heating plate. The shielding plates contain connections for supplying and draining working fluids [15]. These devices are used in hot utility water systems, in central heating installations, geothermal and solar heating systems, in heat pump installations, with fireplace and water jacket and others. Therefore, the materials from which they are made must meet strictly defined criteria with respect to strength parameters and operating conditions. This heat exchanger is made entirely of 316L austenitic stainless steel. An example of qualifying brazing technology will be made for heating plates (Fig. 3, element 2). Vacuum brazing (Furnace Brazing) was used for the joining process using a Seco Warwick furnace, type 60VPT4035/36HV. Input data for the design of brazing technology:

- thickness and grade of the heating plate material: $t=0.4 \mathrm{~mm}$, austenitic stainless steel $316 \mathrm{~L}$, table I; P-No. 102 according to table QW/QB-422 in Sec. IX;

- connector type: lap joint (overlap $5.0 \mathrm{~mm}$ );

- brazing filler metal form and grade: tape, $\mathrm{t}=0.12 \mathrm{~mm}$, designation according to SFA 5.8: $\mathrm{BCu}-3$, table I;

- maximum working temperature: $230^{\circ} \mathrm{C}$;

- maximum working pressure: $3 \mathrm{MPa}$;

- working medium: water, glycol;

- flow position: position A(1), QB-407, QB-461.2.

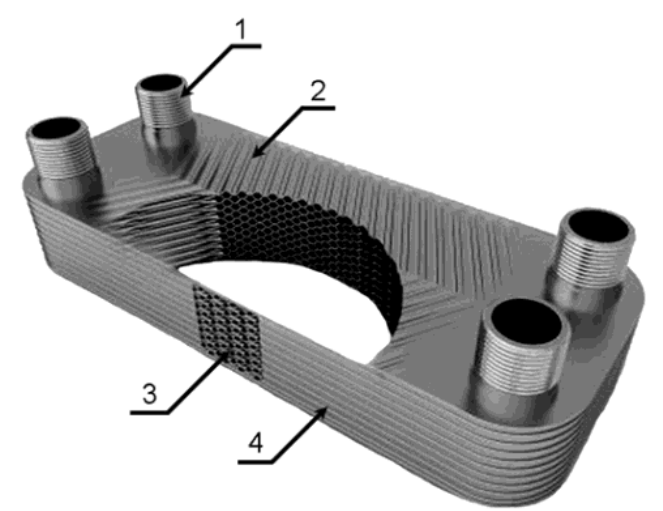

Fig. 3. Construction of a plate heat exchanger, where: 1 - nozzle, 2 - heating plates of variable geometry (profiled), 3 - flow channel system, 4 - brazed joints [15]

Table I. Properties and chemical composition of materials used for tests

\begin{tabular}{|c|c|c|c|c|c|c|c|c|}
\hline \multicolumn{9}{|c|}{ Chemical composition of $316 \mathrm{~L}$ steel, \%wt. in accordance with the certificate 3.1} \\
\hline $\mathrm{C}$ & $\mathrm{Si}$ & $\mathrm{Mn}$ & $\mathrm{Ni}$ & $\mathrm{Cr}$ & Mo & $\mathrm{N}$ & $\mathrm{S}$ & $\mathrm{P}$ \\
\hline 0.02 & 0.36 & 1.25 & 10.01 & 16.64 & 2.02 & 0.031 & 0.0038 & 0.029 \\
\hline \multicolumn{9}{|c|}{ Strength properties of 316L steel in accordance with the certificate 3.1} \\
\hline & $\mathrm{R}_{\mathrm{m}}[\mathrm{MPa}]$ & & & $\mathrm{R}_{\mathrm{p} 0,2}[\mathrm{MP}$ & & & $\mathrm{A}_{80}[\%]$ & \\
\hline & 621 & & & 295 & & & 52 & \\
\hline \multicolumn{9}{|c|}{ Chemical composition of $\mathrm{BCu}-3, \%$ wt. in accordance with the certificate 3.1} \\
\hline & $\mathrm{Cu}$ & & & $\mathrm{Bi}$ & & & $\mathrm{Pb}$ & \\
\hline & 99.99443 & & & 0.00004 & & & 0.00003 & \\
\hline
\end{tabular}

The brazing temperature was $1120^{\circ} \mathrm{C}$, the vacuum pressure $1.4 \mathrm{mbar}$, the gas filling the furnace is nitrogen at 0.4 bar pressure. The process was carried out in stages by heating with stops to brazing temperature (90 $\mathrm{min})$, enduring at the set temperature (180 $\mathrm{min}$ ) and stage cooling (170 $\mathrm{min})$.

\section{Analysis of the regulations of ASME Sec. IX and Sec. VIII div.1 regarding vacuum brazing}

Regulations of ASME Sec. IX relate to the qualification of welding technology, brazing, joining plastics and certification of welders, brazers and operators. The latest edition of 2017 contains 350 pages divided into relevant parts and annexes (mandatory and optional, numbering B, D, E, F, G, H, J, K, L). The structure of the regulations distinguishes parts concerning general requirements (marked as QG), welding (marked 
as $\mathrm{QW}$ ), brazing (marked as $\mathrm{QB}$ ), and plastic joining (QF). Each part also contains articles (subchapters), the designation of which is related to a given area of application (the designation is a combination of a letter and digital abbreviation, e.g. QB-250, regarding the main variables of the brazing process). The articles provide detailed information for each process and other related variables that are covered by these provisions. The discussed regulations are very extensive and their detailed description requires separate publication. For this reason, the rest of the article describes the code elements that are directly related to the qualification process of furnace brazing. It should also be added that an important element in the qualification of brazing and welding technologies is to take into account the design rules that result in additional guidelines for testing and acceptance criteria, e.g. extension of strength tests with additional samples, performance of impact tests and others. In the case under consideration this is Section VIII, Div.1 (Regulations regarding the construction of pressure vessels). Section IX brazing is described in part QB, which includes: article XI general requirements for brazing (subchapters from QB-100 to QB-180), article XII qualification of brazing technology (subchapters from QB-200 to QB-250), article XIII qualification of brazing personnel (subchapters from QB-300 to QB-350), article XIV data of the brazing process (subchapters from QB-400 to QB-460). As in the case of European standards, also in this case it is required to specify the relevant input data that allow defining the variables affecting the process. The basic ones include: grade of basic material, construction of joints, type, form and grade of brazing filler metal, thickness of connected elements and other e.g. resulting from operating conditions (temperature, pressure, working medium). Documenting the brazing process involves creating a Brazing Procedure Specification (BPS) based on the qualification of the process confirmed by the Procedure Qualification Record described in QB-200.2. BPS includes and describes variables that are essential and nonessential to a given process and may contain other additional information that plays an important role in the brazing process. This document can be changed without the need for a re-qualification process if nonessential variables change and are documented. In the case of essential variable changes, the process must be reassessed (new or additional PQR) and the creation of a new BPS. Regulations of ASME Sec. IX cite the example format of the BPS brazing instruction in subsection QB-482 (optional attachment B) and in subsection QB-483 (optional attachment B) an example of the PQR form. Both of these formats are only a guide for creating a document. The organization has the option of editing them to suit your needs, provided that you include the variables given in QB-250 (QB-253 for vacuum brazing). Table II presents the variables that are essential and nonessential for vacuum brazing for which the qualification procedure was carried out.

Table II. Essential and nonessential variables for furnace brazing acc. to ASME Sec. IX, QB-253

\begin{tabular}{ccc}
\hline $\begin{array}{c}\text { Paragraph provisions } \\
\text { ASME Sec. IX }\end{array}$ & 253.1 Essential variables & 253.2 Nonessential variables \\
\hline QB-402 Base Metal & QB-402.1 & - \\
QB-403 Brazing Filler Metal & QB-402.2 & - \\
& QB-403.1 & - \\
QB-404 Brazing temperature & QB-403.2 & - \\
QB-406 Brazing Flux, gas, or atmosphere & QB-403.3 & - \\
QB-407 Flow position & QB-404.1 & - \\
& QB-406.1 & - \\
QB-408 Joint design & QB-406.2 & - \\
& QB-407.1 & - \\
QB-4.11 Brazing time & QB-408.2 & - \\
QB-409 Postbraze Heat Treatment & QB-408.4 & - \\
& QB-409.1 & QB-411.1 \\
\hline
\end{tabular}


It is important that the protocol on qualified brazing technology (PQR) is confirmed by the manufacturer (the so-called organization). These regulations do not carry out the procedure for qualifying the brazing technology of an external organization, because it itself must prove and verify the process used together with the specified variables. This must be supported by appropriate tests, which are carried out on the basis of appropriate guidelines presented in subsection QB-451. In order for the qualified brazing technology to be recognized as correct, the obtained test results must meet specific acceptance criteria, e.g. in relation to strength or metallographic properties.

In addition to the test results, additional drawings and information can be recalled in PQR if they are relevant to the brazing process used. The regulations allow the execution of the Brazing Technology Instruction based on one or more PQRs. The developed technical documentation must be available on request to the Authorized Inspector (AUTHORIZED INSPECTOR - AI) for its review and verification, and above all for brazers and brazing operators.

The scope of tests and their number depends on the type of brazed joints. They are respectively presented in the following chapters:

1. Butt joint and a scarf joint: QB-451.1, QB-451.2 (Fig. 4b and 4c).

2. Lap joint: QB-451.3 (Fig. 4a).

3. Rabbet joint: QB-451.4 (Fig. 4d).

4. Workmanship coupons not including joints from points 1 to 3: QB-451.5 (Fig. 4e).

a)

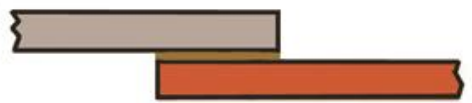

b)

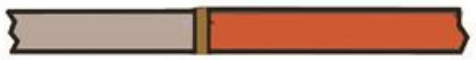

c)

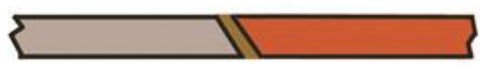

d)
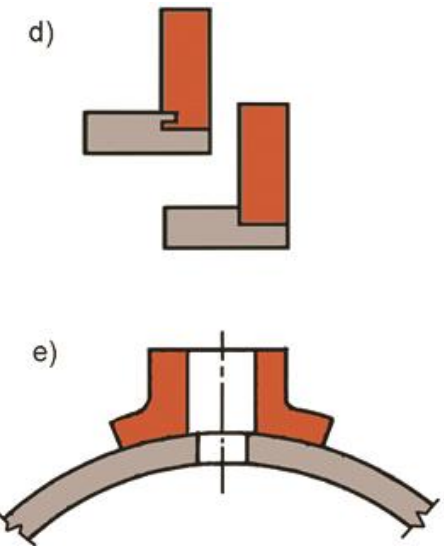

Fig. 4. Types of brazed joints: a) lap, b) butt, c) scarf, d) rabbet, e) workmanship coupons

In the case under consideration, the process will be qualified for lap joints. Guidelines regarding the scope of qualifications for the thickness of joined elements, type of tests, number of samples and additional guidelines are presented in Sec. IX, paragraph QB-451.3 (Table III).

Table III. Range of thickness of materials qualified by test and type and number of tests acc. to ASME Sec. IX, QB451.3 for lap joints

\begin{tabular}{ccccc}
\hline $\begin{array}{c}\text { Thickness T of Test } \\
\text { Coupon as Brazed } \\
\text { [mm] }\end{array}$ & $\begin{array}{c}\text { Qualified thickness range } \\
\text { for brazed elements made } \\
\text { of sheet or pipe [mm] }\end{array}$ & $\begin{array}{c}\text { Type and number of tests, specimens } \\
\text { required } \\
\text { [Note 1] }\end{array}$ & $\begin{array}{c}\text { Peel test } \\
\text { [Note 3] and [Note 4] }\end{array}$ \\
\hline T Min. & T Max. & $\begin{array}{c}\text { Tensile test } \\
\text { [Note 2] }\end{array}$ & 2 & 2 \\
\hline Less than $3 \mathrm{~mm}$ & $0.5 T$ & $2 T$ & 2 & 2 \\
From 3 to $10 \mathrm{~mm}$ & 1.5 & $2 T$ & 2 & 2 \\
Over $10 \mathrm{~mm}$ & 5 & $2 T$ & & 2 \\
\hline
\end{tabular}

Notes:

(1) When materials of a representative geometry and thickness are not available to prepare butt or lap joint test coupons, workmanship coupons may be prepared and examined per QB-451.5 to establish the range of thickness of base metal qualified. When this is done, the properties of the joint shall be validated using butt or lap joint test coupons of any thickness.

(2) For specimen dimensions, see Figure QB-462.1(c). For pipe specimens not greater than NPS 3 (DN 75), full section testing may be substituted; see Figure QB-462.1(e).

(3) For peel specimens, see Figure QB-462.3 for specimen dimensions, and Figure QB-463.1(d) for specimen removal.

(4) Sectioning tests may be substituted for peel tests. For section specimens, see Figure QB-462.4 for specimen dimensions, and Figure QB-463.1(c) for specimen removal. 
When designing plate heat exchangers, important data is the so-called work parameters. These are extremely important variables that determine the design and materials used. Such input data include type of working medium, working pressure and working temperature. In the analyzed case, the operating temperature was set at $230{ }^{\circ} \mathrm{C}$ (information in the input data for technology design). In this case, it is necessary to take into account the design rules, which are associated not only with the design itself, but also with additional requirements, among others, with regard to brazing. For the heat exchanger under consideration, these are the requirements of the provisions of ASME Sec. VIII div.1, paragraphs UB-2 and UB-12. They refer to the operating temperature in relation to the BCu-3 filler metal and the additional tests resulting from it. Table IV presents the permissible maximum design temperatures for brazing additional materials in accordance with UB-2.

Table IV. Maximum design temperatures for brazing filler metal (table UB-2. Sec. VIII div.1)

\begin{tabular}{ccc}
\hline $\begin{array}{c}\text { Classification of brazing } \\
\text { filler metal material }\end{array}$ & $\begin{array}{c}\text { Column } \mathbf{1} \\
\text { Temperature }\left[{ }^{\circ} \mathrm{C}\right] \text {, below } \\
\text { which only tests according } \\
\text { to Sec. IX are required }\end{array}$ & $\begin{array}{c}\text { Column } \mathbf{2} \\
\text { Temperature }\left[{ }^{\circ} \mathbf{C} \text { ] at which tests }\right. \\
\text { according to Sec. IX and additional } \\
\text { research are required }\end{array}$ \\
\hline BCuP & 150 & $150 \div 180$ \\
BAg & 200 & $200 \div 260$ \\
BCuZn & 200 & $200 \div 260$ \\
BCu & 200 & $200 \div 340$ \\
BAlSi & 150 & $150 \div 180$ \\
BNi & 650 & $650 \div 815$ \\
BAu & 430 & $430 \div 480$ \\
BMg & 120 & $120 \div 135$ \\
\hline
\end{tabular}

For qualified brazing technology, the requirements of table IV should be taken into account. In the case of the brazing with the designation $\mathrm{BCu}-3$ and the working temperature $\left(230{ }^{\circ} \mathrm{C}\right)$, it results (column 2 in Table IV) that outside the scope of tests, which is a consequence of the data from Table III (ASME Sec. IX, QB-451.3) additional tests specified in paragraph UB-12 Sec. VIII div.1 should be performed. This is a tensile test of brazed joints at design temperature $(\mathrm{T})$ and elevated and calculated according to dependencies 1.05T. Bearing in mind the presented guidelines, the scope of tests for this vacuum brazing technology is as follows:

1. Visual tests in accordance with the requirements of ASME Sec. V, Article 9 (Visual Examination);

2. Tensile tests according to QB-150:

a) two samples stretched at room temperature;

b) one sample stretched at design temperature, $230^{\circ} \mathrm{C}$;

c) one sample stretched at $1.05 \mathrm{~T}, 242^{\circ} \mathrm{C}$;

3. Sectioning tests that will replace the peel test (Note 4 in Table III) in accordance with the requirements of QB-180.

Similarly to the EN ISO standards, the ASME regulations also provide a certain degree of recognition for individual essential variables. According to table III (QB-451.3), the scope of approval for thickness is $\mathrm{T}=0.2 \div 0.8 \mathrm{~mm}$, for the lap $\mathrm{L}>5.0 \mathrm{~mm}(\mathrm{QB}-408.2)$, for clearance $\mathrm{c} \leq 0.12 \mathrm{~mm}(\mathrm{QB}-408.4)$.

\section{Test results}

\section{Visual testing}

Visual testing (VT) is mandatory and must be used for all devices that comply with ASME regulations. All brazed joints made as part of brazing technology qualification are subject to visual examination. Requirements Art.1, Sec. V "General requirements" refer to VT Visual Tests in accordance with Art. 9, Sec. V for the requirements of Sec. VIII Div 1. As part of the tests, the surface quality was verified. There was no discoloration, inclusions of other material or excess filler metal on the surface. No cracks were found in the base material or brazing joint, pores or other brazing incompatibilities, which meets the requirements of UB-44 Sec. VIII div.1. After a positive assessment of the test joints made, they were passed on to subsequent tests.

\section{Tensile test of the brazed joints}

Tensile tests of brazed joints are one of the basic tests performed as part of qualifying brazing technology. In section IX ASME, the test characteristics with relevant references are presented in chapter 
QB-150. Samples were prepared in accordance with the requirements presented in QB-462.1 (c) for lap joints made of sheet metal (sample dimensions thickness $x$ width $\times$ length: $0.39 \times 19.0 \times 350 \mathrm{~mm}$ ). The test procedure is described in QB-152. This point states that the joint subjected to the test must be torn apart under tensile load. The tensile strength is calculated by dividing the final total load by the smallest crosssectional area of the sample measured before the load is applied. Acceptance criteria are adopted in accordance with QB-153. The minimum values of tensile strength referred to in the process of qualifying brazing technology are given in QW/QB-422. In item QB-153.1 acceptance criteria for various cases are given in items a) to d). For the discussed solution and the used P-No 8 material group (single-sign joint) the acceptance criterion is described in item a). In this case, the tensile strength value obtained should be equal to the minimum strength for the base material used. For 316L steel according to SA-240 and ambient temperature $\left(23{ }^{\circ} \mathrm{C}\right)$ it is $485 \mathrm{MPa}$. For elevated temperatures, the rupture point was adopted as the acceptance criterion, which means that the strength of the brazed joint at a given temperature is higher than for the base material. The obtained test results are presented in table $\mathrm{V}$.

\begin{tabular}{cccccc}
\multicolumn{2}{l}{ Table V. Results of strength tests } \\
\hline $\begin{array}{c}\text { Designation } \\
\text { of the sample }\end{array}$ & $\begin{array}{c}\text { Test } \\
\text { temperature }\left[{ }^{\circ} \mathbf{C} \text { ] }\right.\end{array}$ & $\begin{array}{c}\text { Tensile strength } \\
\mathbf{R}_{\mathbf{m}}[\mathbf{M P a}]\end{array}$ & $\begin{array}{c}\text { Acceptance } \\
\text { criterion } \mathbf{R}_{\mathbf{m}}[\mathbf{M P a}]\end{array}$ & Rupture place & Test result \\
\hline LUT 01/1 & 23 & 670 & 485 & base metals & positive \\
LUT 01/2 & 23 & 662 & 485 & base metals & positive \\
LUT 01/3 & 230 & 390 & rupture place & base metals & positive \\
LUT 01/4 & 242 & 378 & rupture place & base metals & positive \\
\hline
\end{tabular}

The obtained test results entitle to state that the brazing parameters used and additional technological procedures (positioning of elements, clearance, downforce of elements and others) allowed to obtain joints meeting the assumed acceptance criteria. Thus, in the examined scope they meet the requirements of the provisions of ASME Sec. IX and Sec. VIII div.1.

\section{Sectioning tests}

Sectioning tests are defined in Sec. IX at point QB-180. QB-181 sets out the requirements for sample preparation for testing. The dimensions of the samples and the place of their collection from the test joints are presented in QB-462.4. Each sample should be properly prepared by grinding and polishing, and then examined at a magnification of at least $\mathrm{x} 4$. As the acceptance criterion, it was assumed that the sum of the lengths of the unconnected areas (separately for each side of the sample) must not exceed $20 \%$ of the length of the joint's overlap. Tests should be performed for each side of the brazed joint. For the test joints made, the preparation process consisted of the mounting of samples, gradual grinding to 2000 paper gradation, and then polishing on diamond paste. Samples were not digested due to different physicochemical properties of the brazed filler metal and the base material. The tests were performed on an OLYMPUS BX52 metallographic microscope. Photographs of metallographic specimens are shown in figure 5.

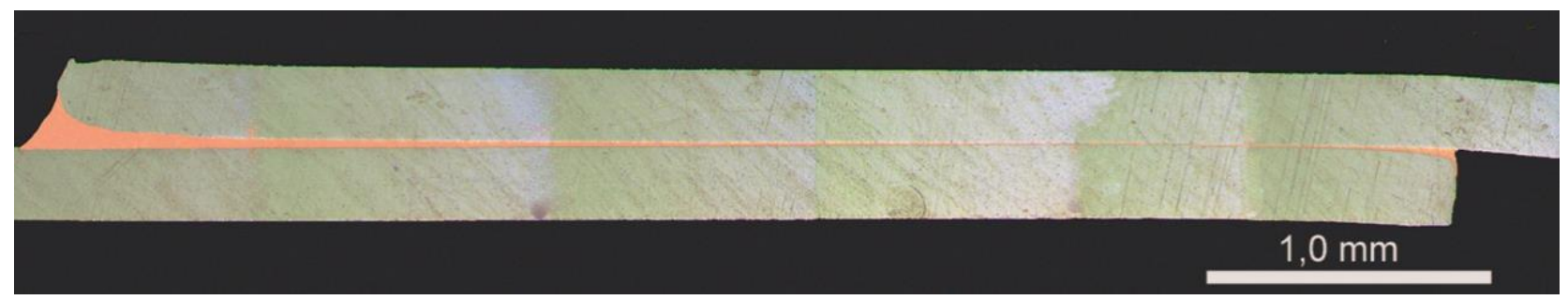

(a)

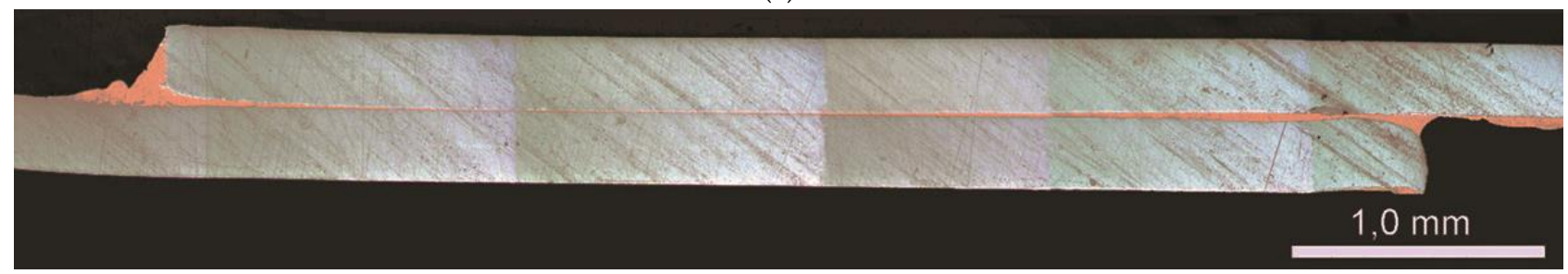

(b)

Fig. 5. Macroscopic photographs of brazed joints 
Analyzing figures $5 \mathrm{a}$ and $5 \mathrm{~b}$, it can be concluded that filler metal fills the brazing gap along the entire length of the overlap (100\%). There was no lack of filling in the clearance, pores and gas bubbles, which is a common imperfection. They result from an improperly prepared surface for brazing (no thorough cleaning), failure to maintain an even brazing clearance (BCu-3 filler metal is less sensitive to such changes), uneven pressure of heating plates, changes in vacuum during brazing, contamination of the cooling gas at the cooling stage. No cracks were identified, which is extremely important from the point of view of fatigue strength. The obtained results meet the acceptance criterion specified in QB-181, 20\% of not filling the brazing clearance. In this case, the result is considered positive.

The obtained test results authorize the preparation of a report on the qualification of $P Q R$ of the brazing technology and Brazing Procedure Specification. An example of BPS made in accordance with the requirements of ASME Sec. IX based on qualified brazing technology is shown in figure 6.

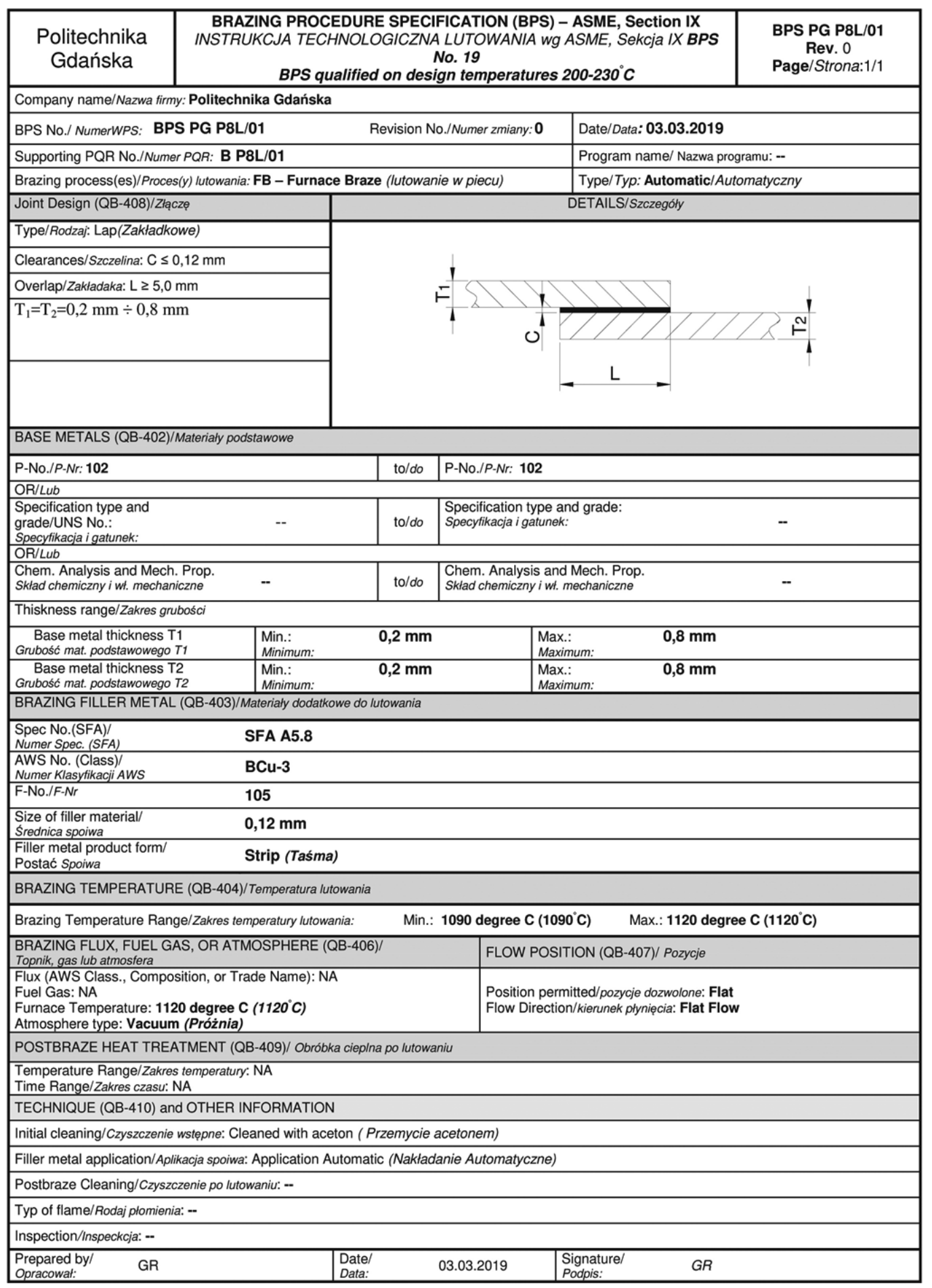

Fig. 6. An example of BPS made in accordance with ASME Sec. IX for the case under consideration 


\section{Conclusions}

Based on an analysis of ASME Sec. IX and Sec. VIII div. 1 and the results of the tests carried out, the following conclusions can be drawn:

1. Analysis of the provisions of ASME Sec. IX and Sec. VIII div. 1 allowed to determine the appropriate scope of tests, which takes into account the construction and welding requirements. It should be remembered that in addition to the requirements of ASME Sec. IX regarding welding and brazing, the design regulations guidelines (ASME Sec. VIII div.1) must always be taken into account. This can lead to the extension of the scope of required tests.

2. An important element of designing brazing technology is knowledge of the construction requirements (joint design, size of the overlap, size of the clearances, direction of flow, etc.) and operating parameters (temperature, pressure, working medium). This allows for a detailed analysis and determination of the appropriate test schedule in accordance with the code requirements for the device in question.

3. The results of non-destructive examination (VT) and destructive tests (tensile test, sectioning tests) of brazed joints of the heat exchanger meet the assumed acceptance criteria in accordance with the code requirements. This allows the preparation of a protocol from Procedure Qualification Record (PQR) with a positive result and the Brazing Procedure Specification (BPS).

4. In the case of vacuum brazing, an extremely important role is played by the process of brazing consisting of stage heating, then withstanding at brazing temperature and stage cooling. The selection of these parameters must be supported by technological tests that allow the determination of optimal ranges of essential variables of the process.

Author Contributions: methodology G.R. and J.Ł.; investigation G.R, M.L. and A.Ś.; writing - original draft preparation G.R, J.T, A.Ś and M.L.; writing - review and editing G.R. and A.Ś.

Acknowledgments: The authors thank SECESPOL Sp. $\mathrm{z}$ o.o. for the manufacturing of test joints, which were used to conduct the tests.

Conflicts of Interest: The authors declare no conflict of interest.

\section{Resources}

[1] Li Y., Zhang X., Parfitt D., Jones S., Chen B., Characterisation of microstructure, defect and high-cycle-fatigue behaviour in a stainless steel joint processed by brazing. Materials Characterization, 2019, Vol. 151, 542-552.

[CrossRef]

[2] Tomków J., Haras J., Types of surface impurities versus the quality of brazed joints. Biuletyn Instytutu Spawalnictwa w Gliwicach, 2018, Vol. 62(4), 53-58. [CrossRef]

[3] Heo H., Kim G., Kim D.Y., Moon C., Kim K.C., Jung K., Kang, C.Y., Microstructure and mechanical properties of $\mathrm{Ni}$ foam/stainless steel joint brazed using Ni-based alloy. Materials Science and Engineering: A, 2019, Vol. 740-741, 63-70. [CrossRef]

[4] Wang N., Wang D.P., Yang Z.W., Wang Y., Liu X.G., Zirconia ceramic and Nb joints brazed with Mo-particlereinforced $\mathrm{Ag}-\mathrm{Cu}-\mathrm{Ti}$ composite fillers: interfacial microstructure and formation mechanism. Ceramics International, 2017, Vol. 43(13), 9636-9643. [CrossRef]

[5] Zhu W., Zhang H., Guo C., Liu Y., Ran X., Wetting and brazing characteristic of high nitrogen austenitic stainless steel and 316L austenitic stainless steel by Ag-Cu filler. Vacuum, 2019, 166, 97-106. [CrossRef]

[6] Piwowarczyk T., Mirski Z., Winiowski A., Drzeniek H., Dokumentowanie procesu lutowania oraz egzaminowanie lutowaczy i operatorów lutowania twardego wg PN-EN ISO 13585:2012. Welding Technology Review, 2013, Vol. 85(9), 55-63. [CrossRef]

[7] Mirski Z., Pabian J., Modern trends in production of brazed heat exchangers for automotive industry. Welding Technology Review, 2017, Vol. 89(8), 5-12. [CrossRef]

[8] Xia Y., Dong H., Hao X., Li P., Li S., Vacuum brazing of Ti6Al4V alloy to 316L stainless steel using a Ti-Cubased amorphous filler metal. Journal of Materials Processing Technology, 2019, 269, 35-44. [CrossRef]

[9] Shi J.M., Zhang L.X., Liu H., Sun Z., Feng J.C., Vacuum brazing of SiBCN ceramic and TC4 alloy using TiB2 reinforced AgTi composite filler. Vacuum, 2018, Vol. 156, 108-114. [CrossRef]

[10] Chen Z.B., Bian H., Hu S.P., Song X.G., Niu C.N., Duan X.K., Cao J., Feng, J.C., Surface modification on wetting and vacuum brazing behavior of graphite using $\mathrm{AgCu}$ filler metal. Surface and Coatings Technology, 2018, Vol. 348, 104-110. [CrossRef] 
[11] Bielanik J., Lutowanie próżniowe elementów kół wirnikowych turbosprężarki z martenzytycznej stali typu 13-4, Politechnika Warszawska, Laboratorium Materiałoznawstwa Wydział Budownictwa, Mechaniki i Petrochemii w Płocku, PL0400064. [Hyperlink]

[12] Kowalewski J., Szczurek J., Issues in Vacuum Brazing, [Hyperlink]

[13] BRO-0010.4 - An Introduction to Brazing. Issue 4, [Hyperlink]

[14] Skrzypek S.J., Goły M., Korzeń T., Dul I., Babul T., Choroszynski M., Analiza fazowa złączy superstopów niklu ze stalą austenityczną lutowanych próżniowo. Welding Technology Review, 2013, Vol. 85(8), 41-44. [CrossRef]

[15] www.secespol.com

[16] Świerczyńska A., Rogalski G., Fydrych D. Badania struktury i właściwości spawanych austenitycznych rur wymienników ciepła. Welding Technology Review, 2010, Vol. 82(6), 11-16.

[17] Rogalski G., Świerczyńska A., Fydrych D., Landowski, M., The influence of solution annealing temperature on the properties of Lean Duplex 2101 welded joints in tubes. Welding Technology Review, 2019, Vol. 91(4), 49-59. [CrossRef]

[18] Guo D., Kwok C.T., Chan S.L.I., Spindle speed in friction surfacing of 316L stainless steel-How it affects the microstructure, hardness and pitting corrosion resistance. Surface and Coatings Technology, 2019, Vol. 361, 324341. [CrossRef]

[19] Kangazian J., Shamanian M., Micro-texture and corrosion behavior of dissimilar joints of UNS S32750 stainless steel/UNS N08825 Ni-based superalloy. Materials Characterization, 2019, 155, 109802. [CrossRef]

[20] Josz K., ASME standards as a key to new markets. Quarterly TÜV NORD Polska, 2012, 4.

(C) 2019 by the authors. Submitted for possible open access publication under the terms and conditions of the Creative Commons Attribution (CC BY) license (http://creativecommons.org/licenses/by/4.0/). 